University of Nebraska - Lincoln

DigitalCommons@University of Nebraska - Lincoln

2011

\title{
A Multi-Year Comparison of IPCI Scores for Prairie Pothole Wetlands: Implications of Temporal and Spatial Variation
}

Ned H. Euliss Jr.

U.S. Geological Survey, ceuliss@usgs.gov

David M. Mushet

U.S. Geological Survey, dmushet@usgs.gov

Follow this and additional works at: https://digitalcommons.unl.edu/usgsnpwrc

Euliss, Ned H. Jr. and Mushet, David M., "A Multi-Year Comparison of IPCI Scores for Prairie Pothole Wetlands: Implications of Temporal and Spatial Variation" (2011). USGS Northern Prairie Wildlife Research Center. 273.

https://digitalcommons.unl.edu/usgsnpwrc/273

This Article is brought to you for free and open access by the US Geological Survey at DigitalCommons@University of Nebraska - Lincoln. It has been accepted for inclusion in USGS Northern Prairie Wildlife Research Center by an authorized administrator of DigitalCommons@University of Nebraska - Lincoln. 


\title{
A Multi-Year Comparison of IPCI Scores for Prairie Pothole Wetlands: Implications of Temporal and Spatial Variation
}

\author{
Ned H. Euliss Jr. • David M. Mushet
}

Received: 1 December 2010 /Accepted: 17 May 2011 /Published online: 16 June 2011

(C) US Government 2011

\begin{abstract}
In the prairie pothole region of North America, development of Indices of Biotic Integrity (IBIs) to detect anthropogenic impacts on wetlands has been hampered by naturally dynamic inter-annual climate fluctuations. Of multiple efforts to develop IBIs for prairie pothole wetlands, only one, the Index of Plant Community Integrity (IPCI), has reported success. We evaluated the IPCI and its ability to distinguish between natural and anthropogenic variation using plant community data collected from 16 wetlands over a 4-year-period. We found that under constant anthropogenic influence, IPCI metric scores and condition ratings varied annually in response to environmental variation driven primarily by natural climate variation. Artificially forcing wetlands that occur along continuous hydrologic gradients into a limited number of discrete classes (e.g., temporary, seasonal, and semipermanent) further confounded the utility of IPCI metrics. Because IPCI scores vary significantly due to natural climate dynamics as well as human impacts, methodology must be developed that adequately partitions natural and anthropogenically induced variation along continuous hydrologic gradients. Until such methodology is developed, the use of the IPCI to evaluate prairie pothole wetlands creates potential for misdirected corrective or regulatory actions, impairment of natural wetland functional processes, and erosion of public confidence in the wetland sciences.
\end{abstract}

Electronic supplementary material The online version of this article (doi:10.1007/s13157-011-0187-2) contains supplementary material, which is available to authorized users.

N. H. Euliss Jr. $(\bowtie) \cdot$ D. M. Mushet

U.S. Geological Survey,

Northern Prairie Wildlife Research Center,

871137 Street SE,

Jamestown, ND 58401-7317, USA

e-mail: ceuliss@usgs.gov
Keywords Assessment · Biocriteria · Floristic quality Metrics $\cdot$ IBI $\cdot$ Wetland condition

\section{Introduction}

Concern over the sustainability of ecosystems and their provisioning of services has generated considerable interest in developing tools that can rapidly quantify ecosystem condition. One highly valued ecosystem service is biodiversity provisioning, and Indices of Biotic Integrity (IBIs) have been developed as tools to assess human impacts on biotic communities. IBI development first began using fish from the Midwestern United States to characterize anthropogenic degradation of fish communities in streams (Karr 1981; Karr et al. 1986; Karr 1991). The IBI developed by Karr (1981) was based on the premise that some biotic ecosystem components (i.e., "metrics") have foreseeable reactions to anthropogenic disturbances. These "metrics" can be useful for assessing system quality if they display consistent quantitative change over a gradient of anthropogenic disturbance (Karr and Chu 1997). If such metrics are identified, they can be used to rapidly categorize community condition and inform managers, regulators, and others of potential negative impacts. Similar efforts have been initiated for wetlands using other biota (e.g., DeKeyser 2000; Hanson and Castelle 2001; Simon et al. 2001; Wilcox et al. 2002; DeKeyser et al. 2003; Tangen et al. 2003; Miller et al. 2006; Mack 2007; Hargiss et al. 2008).

In Great Lakes wetlands, Wilcox et al. (2002) found that IBI scores varied within the same wetland over time with no corresponding change in the level of human disturbance. They concluded that this natural variability precluded development of IBIs for Great Lakes wetlands and suggested that wetlands in other geographic areas where 
dynamic hydrologic variations are the norm would also be poor candidates for IBI development. They specifically identified the prairie pothole region (PPR) as falling into this category. Therefore, it is not surprising that efforts to develop IBIs for PPR wetlands have reported mixed results. As predicted by Wilcox et al. (2002), Tangen et al. (2003) were unable to identify useful IBI metrics using aquatic macroinvertebrates in PPR wetlands. In contrast, DeKeyser et al. (2003) reported success in developing an IBI using plant community metrics for seasonal PPR wetlands and later expanded their methodology to include temporary and semi-permanent wetlands (Kirby and DeKeyser 2003; Hargiss et al. 2008). DeKeyser et al. (2003) reported that their evaluation system, the Index of Plant Community Integrity (IPCI), effectively categorized anthropogenic disturbance effects on wetland plant communities into quality classes (e.g., very good, good, fair, poor, and very poor) for mitigation and ecological purposes.

Prairie wetlands are well known for their variable biotic communities (Harris and Marshall 1963; Weller and Spatcher 1965; Stewart and Kantrud 1971; van der Valk and Davis 1978; Euliss et al. 2004; van der Valk 2005), a result of highly dynamic inter-annual climate variations and hydrologic processes (see review in Euliss et al. 2004). The interactions between groundwater and surface water in these wetlands are complex (Winter and Rosenberry 1995, 1998), resulting in individual wetlands performing groundwater recharge, flow-through, or discharge functions (Winter 1989). These functions can vary both seasonally or on an inter-annual basis (Winter 2003a). The interaction of dynamic inter-annual climates, hydrologic processes, and glacial soils creates highly variable and constantly changing habitat conditions that support the region's equally dynamic biotic communities (Euliss et al. 2004).

In addition to dynamic hydrologic, climate, and geochemical features, biotic communities of the PPR evolved under a variety of natural disturbances, including drought (Woodhouse and Overpeck 1998), deluge (Winter and Rosenberry 1998), grazing by native ungulates (McNaughton 1979, 1986), and fire (Raby 1966; Nelson and England 1971; Higgens 1984). Disturbance was such a natural part of the pre-settlement landscape that lack of disturbance is considered to have a negative influence on the quality of native plant communities (Kantrud and Newton 1996; DeKeyser et al. 2003). Long-term studies of prairie pothole wetlands spanning over 40 years demonstrate that an individual wetland can have salt concentrations roughly equivalent to seawater only to freshen up during wet periods to salt concentrations comparable to those of domestic drinking water (see review in Euliss et al. 2004). Such drastic changes result in complete shifts from salt-tolerant biological communities to ones that contain only freshwater species. While not all prairie wetlands undergo such dramatic shifts, numerous studies have demonstrated significant temporal shifts in the composition of their biological communities (see review in Euliss et al. 2004). Thus, we hypothesized that inherent high natural variability has potential to confound IBI assessments. The objective of our study was to compare IPCI scores and resultant condition ratings across years in a series of wetlands where anthropogenic influences have been held constant. To facilitate testing of our hypothesis, we calculated IPCI scores for 16 prairie pothole wetlands that are situated within a contiguous grassland area, the Cottonwood Lake Study Area (CLSA). Thirteen of these wetlands have received consistent and similar levels of anthropogenic influence over the past 47 years. The remaining three wetlands are situated on the borders of the grassland area where they have received some degree of anthropogenic disturbance due to grazing, haying, or cropping within their catchment area. However, while the types and levels of disturbance of these three wetlands have been different from the other 13 wetlands, the types and levels of disturbance for all 16 wetlands remained consistent throughout our study period.

\section{Methods}

\section{Study Area}

The CLSA is a 91.8 ha contiguous block of prairie grassland habitat containing a complex of 16 wetlands located approximately $35 \mathrm{~km}$ northwest of Jamestown, North Dakota, USA (Fig. 1). The CLSA has been under Federal ownership and control since 1963. Due to the relatively unaltered natural hydrologic condition of the CLSA, it has been a primary location for hydrologic, chemical, and biologic investigations of prairie pothole wetlands since 1967 (Winter 2003b). While wetlands at CLSA can be broadly classified as temporary, seasonal, and semi-permanent (Stewart and Kantrud 1971), these discrete classifications do not capture the continuous nature of wetland types of the CLSA, nor of the PPR in general, where wetlands span continuous gradients from groundwater recharge to groundwater discharge (Winter 1989). Long-term research at CLSA has focused on the role of hydrologic variability in shaping prairie wetland biotic communities and has contributed greatly to our understanding of wetland dynamics including formulation of the wetland continuum concept (Euliss et al. 2004) with its central premise that wetlands and their biotic communities occur along temporal and spatial continua that do not neatly fit into discrete wetland classes.

A detailed description of the CLSA's geohydrologic setting, climate, and chemical characteristics of individual wetlands has been provided by Winter (2003a), Rosenberry 


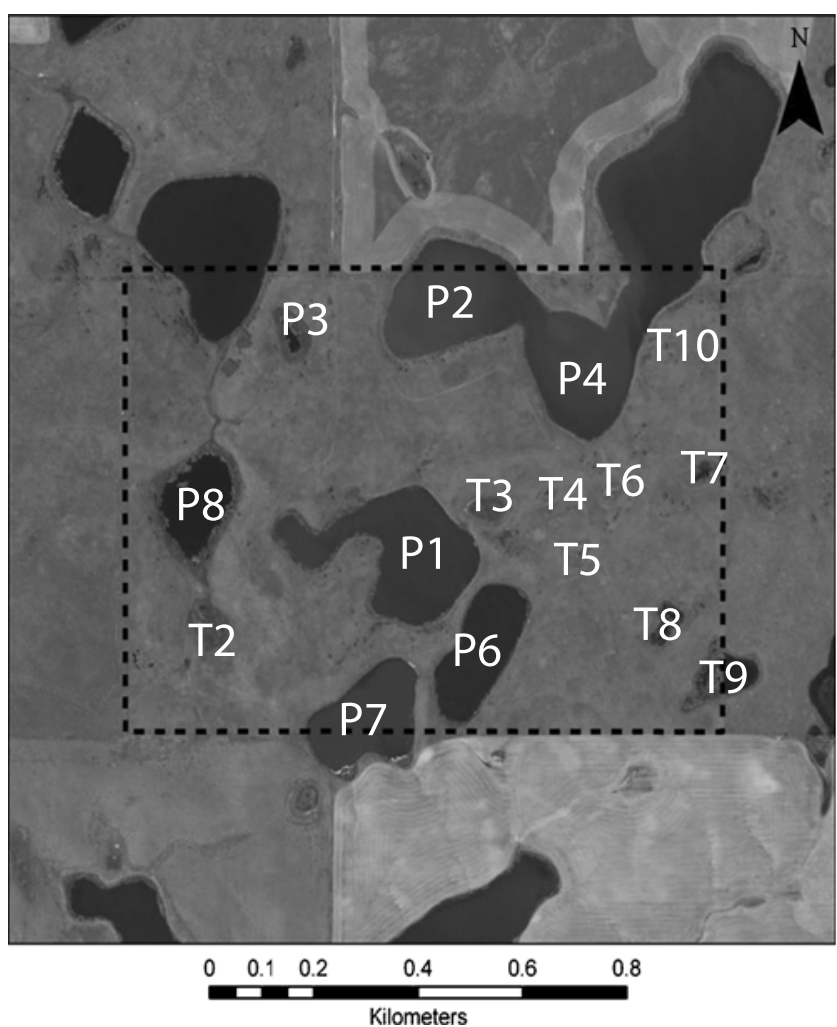

Fig. 1 Location of the wetlands within the Cottonwood Lake Study Area, Stutsman County, North Dakota

(2003), and Labaugh (2003), respectively. Of key relevance to this effort is that for the 47 years that CLSA has been under federal ownership, the site has not been subjected to burning, grazing, spraying, or other management actions typical of many grassland areas. This lack of management influence has largely been due to logistical obstacles related to the presence of numerous groundwater monitoring wells throughout the site. While this lack of management does not represent ideal conditions for promoting the highest quality native prairie plant communities, it does offer the unique opportunity to explore temporal variability of IPCI metrics and condition scores in an area where anthropogenic influence has remained constant over a remarkably long period of time.

We used plant community data from 16 wetlands at CLSA (Fig. 1) collected over a 4-year-period (2007-2010) to facilitate our evaluation of the IPCI. The 16 wetlands, based on the criteria of Stewart and Kantrud (1971), included a single temporary wetland, seven seasonal wetlands, seven semi-permanent wetlands, and a wetland intermediate between a seasonal and semi-permanent classification (Table 1). Three wetlands had catchments that extended beyond the boundaries of the study area onto private lands. The eastern $63 \%$ of wetland T9's catchment extended into an area of private pasture land that is annually grazed by cattle. Likewise, approximately $36 \%$ of wetland P2's catchment is within a grass/alfalfa field that is annually hayed while $65 \%$ of wetland P7's catchment consists of cropland. One wetland utilized in earlier studies that was not identified as a separate wetland in the current effort was wetland $\mathrm{T} 1$. We determined that $\mathrm{T} 1$ is actually a small bay area of wetland P1 (Fig. 1), and therefore we included this area in our survey of wetland P1's plant communities. Water levels in each wetland of the CLSA are measured weekly during the ice-free portion of the year (April to October) from permanent staff gauges calibrated to each wetland's deepest point. Staff gauges are surveyed annually using established benchmarks to account for any movement of gauges due to frost heave or other disturbances.

\section{Sampling}

For each wetland, we compiled comprehensive lists of all plant species occurring in each wetland vegetative zone (deep marsh, shallow marsh, and wet meadow), as well as the low prairie upland zone by exhaustively searching each zone present until no additional species were encountered. Surveys were conducted once each year during the growing season peak to account for temporal variation in plant species development (DeKeyser et al. 2009). All surveys were performed by a trained contractor who has been performing prairie plant surveys for the past 17 years and who has prepared comprehensive listings of plant species in all CLSA wetlands annually for the past 13 years. Voucher

Table 1 Size, classification (Stewart and Kantrud 1971), and hydrologic function (Winter 1987) for 16 wetlands from the Cottonwood Lake Study area, Stutsman County, North Dakota

\begin{tabular}{lcll}
\hline Wetland ID & Size (ha) & Classification & Hydrologic function \\
\hline P1 & 4.6 & IV (Semi-permanent) & Local Discharge \\
P2 & 4.3 & IV (Semi-permanent) & Local Discharge \\
P3 & 0.5 & IV (Semi-permanent) & Flow-through \\
P4 & 4.0 & IV (Semi-permanent) & Local Discharge \\
P6 & 2.9 & IV (Semi-permanent) & Local Discharge \\
P7 & 3.1 & IV (Semi-permanent) & Local Discharge \\
P8 & 3.0 & IV (Semi-permanent) & Local Discharge \\
T2 & 0.8 & Intermediate between & Flow-through \\
T3 & 0.5 & III (Seasonal) & Flow-through \\
T4 & 0.1 & III (Seasonal) & Flow-through \\
T5 & 0.3 & III (Seasonal) & Recharge \\
T6 & 0.2 & III (Seasonal) & Flow-through \\
T7 & 0.4 & III (Seasonal) & Flow-through \\
T8 & 0.7 & III (Seasonal) & Recharge \\
T9 & 0.9 & III (Seasonal) & Recharge \\
T10 & 0.1 & II (Temporary) & Recharge \\
\hline
\end{tabular}


specimens of species collected during surveys are maintained in the U.S. Geological Survey herbarium at the Northern Prairie Wildlife Research Center in Jamestown, North Dakota. As an additional aid to plant surveys, a complete inventory of all plant species occurring in the CLSA (both wetland and upland species) has been compiled (Mushet et al. 2004) and is periodically updated as new species are encountered. Thus, plant species occurrence in CLSA wetlands is exceptionally well known and documented. While comprehensive surveys of wetland plant communities have been conducted at CLSA since 1998 to facilitate evaluations of floristic quality assessment techniques (e.g., Mushet et al. 2002), surveys prior to 2007 did not include information specific to the low prairie (upland) zone immediately adjacent to wetlands. Since data from the low prairie zone is an integral component of the IPCI (Hargiss et al. 2008), we expanded our plant surveys in 2007 to include this upland zone. Thus, while significant information on plant community composition is available for CLSA wetlands since 1998, we restricted our analyses of the IPCI to the 4-year-period (2007-2010) for which data from the low prairie zone were available. Unlike Hargiss et al. (2008), we did not attempt to estimate aerial cover of plant species or distinguish between primary and secondary species because these data are not a component of IPCI metrics identified by DeKeyser et al. (2003).

\section{Condition Scores}

Using the comprehensive species lists developed for each vegetative zone, we calculated IPCI metric scores and overall condition scores for CLSA wetlands as described by Hargiss et al. (2008). DeKeyser et al. (2003) identified nine metrics as having a notable linear change over an anthropogenic disturbance gradient. These nine metrics were:

1) species richness of native perennials,

2) number of genera of native perennials,

3) number of native grass and grass-like species,

4) percentage of annual, biennial, and introduced species of entire species list,

5) number of native perennial species in the wet meadow zone,

6) number of species with a Coefficient of Conservatism value $(\mathrm{C}$-value $) \geq 5$,

7) number of species in the wet meadow zone with a C-value $\geq 4$,

8) average C-value,

9) floristic quality index.

The first five metrics rely on measures of species richness, while the last four metrics rely on Coefficients of Conservatism (hereafter referred to as C-values) derived from Floristic Quality Assessment methodology (Wilhelm and Ladd 1988; Swink and Wilhelm 1994; Taft et al. 1997). Following DeKeyser et al. (2003) and Hargiss et al (2008), we used C-values assigned to the region's plant species by the Northern Great Plains Floristic Quality Assessment Panel (2001) for these last four metrics.

Hargiss et al. (2008) identified three condition classes for temporary and semi-permanent wetlands (poor, fair, and good) and five condition classes for seasonal wetlands (very poor, poor, fair, good, and very good). However, they did not define score ranges needed for assigning wetlands into appropriate condition classes. Using supplemental information associated with the online version of their article, we determined the range of condition scores related to each condition class. Thus, for the temporary wetlands sampled by Hargiss et al. (2008), wetlands with condition ratings falling between zero and 33 were assigned to the "poor" condition class, wetlands with condition ratings $>33$ to 66 were assigned to the "fair condition class, and wetlands with condition ratings $>66$ were assigned to the "good" condition class. Likewise, for semi-permanent wetlands "poor", "fair", and "good" condition classes were associated with ratings of 0 to $33,>33$ to 65 , and $>65$, respectively. The five condition classes of seasonal wetlands were "very poor" (0 to 18$)$, "poor" (>18 to 39$)$, "fair" (>39 to 60 ), "good" (>60 to 78$)$, and "very good" $(>78)$. We used these ranges to place the CLSA wetlands into condition classes based on their condition scores for a particular year.

To gain additional insights into the response of IPCI scores and ratings to the dynamics of prairie wetlands, we utilized plant species lists developed by Stewart and Kantrud (1971). In their classic treatment of prairie wetlands, Stewart and Kantrud (1971) listed dominant and secondary plant species in natural drawdown, normal emergent, and cropland drawdown phases for different wetland types in the PPR derived from investigations of over 450 ponds, lakes, and fens (Stewart and Kantrud 1972). The sites Stewart and Kantrud sampled extended across two physiographic regions (the drift plain and the Coteau du Missouri) of the PPR and four counties (Barnes, Kidder, Logan, and Stutsman) in east-central North Dakota. Although Stewart and Kantrud (1971) provide insufficient information to calculate IPCI or FQI scores, they did provide adequate information to calculate mean c-values of the dominant species.

\section{Results}

Despite no change in anthropogenic disturbance within individual wetlands during the 4 years of our study (and for the preceding 43 years), IPCI quality ratings for CLSA 

condition scores for semi-permanent wetlands ranged from 45 (wetland P4 in 2007) to 95 (wetland P8, also in 2007) with resultant condition ratings that ranged from "fair" to "good". Within semi-permanent wetlands, condition scores fluctuated by an average of 19.3 condition points among years with fluctuations that ranged from 11 to 32 points. Condition scores for wetland $\mathrm{P} 3$ and $\mathrm{P} 7$ fluctuated the least (55-66 and 76-87, respectively) over the 4 years of our study, while condition scores for wetland P2 fluctuated the most (48-80 over the 4 years of our study). For the seven seasonal wetlands sampled, condition scores ranged from 34 (T5 in 2008) to 91 (T3 in both 2007 and 2010). Within individual seasonal wetlands, condition scores fluctuated by an average of 21.1 points among years. Condition scores for wetland $\mathrm{T} 3$ fluctuated the least ( 8 points over the 4 years of our study) while wetland T5 fluctuated the most (33 points over the 4 years of our study). Condition ratings for seasonal wetlands in the CLSA ranged from "poor" (wetland T5 in 2007) to "very good" (Wetland T3 in all 4 years, T6 and T7 in 2010, and wetland T9 in 2007, 2009, and 2010). Overall, ten of the 16 wetlands switched

Table 2 Index of Plant Community Integrity (Hargiss et al. 2008) scores and quality classes for 16 wetlands of the Cottonwood Lake Study Area, Stutsman County, North Dakota, 2007-2010. Condition rating break points for temporary wetlands were 0 to 33 (poor), $>33$ to 66 (fair), and $>66$ (good). Condition rating break points for semipermanent wetlands were 0 to 33 (poor), $>33$ to 65 (fair), and $>65$ wetlands varied considerably (Table 2; Fig. 2). IPCI

condition class at least once during our 4 year study period (Table 2; Fig. 2).

Scores for individual metrics were also highly variable both among wetlands and among years (Electronic Supplemental Materials Tables 1-3). As an example, species richness of native perennials in seasonal wetlands ranged from an average of 37.0 in wetland T5 to 55.5 in wetland T3. Species richness of native perennials in these two wetlands fluctuated from 28 to 45 in wetland T5 and from 50 to 65 in wetland T3 over our 4-year-study-period. Using this same metric but for semi-permanent wetlands, species richness of native perennials ranged from an average of 54.3 in wetland $\mathrm{P} 3$ to 78.3 in wetland $\mathrm{P} 8$, with a fluctuation range of 50 to 59 in wetland $\mathrm{P} 3$ and 74 to 87 in wetland $\mathrm{P} 8$. Species richness of native perennials for our single temporary wetland (wetland T10) averaged 30.5 over our 4-year-study-period.

Water depths of CLSA wetlands varied greatly both among wetlands and among years (Electronic Supplemental Materials Table 4). Over our study period, the mean average-water-depth of seasonal wetlands varied from $0.04 \mathrm{~m}$ in 2008 to $0.45 \mathrm{~m}$ in 2010 . Mean average-

(good). Condition rating break points for seasonal wetlands were 0 to 18 (very poor), $>18$ to 39 (poor), $>39$ to 60 (fair), $>60$ to 78 (good), and $>78$ (very good). Wetland T2 was classified as intermediate between a seasonal and a semi-permanent and was scored using both criteria

\begin{tabular}{|c|c|c|c|c|c|c|c|c|c|c|c|}
\hline \multirow[t]{2}{*}{ Wetland } & \multirow[t]{2}{*}{ Class } & \multicolumn{4}{|c|}{ Condition score } & \multicolumn{4}{|c|}{ Condition rating } & \multirow[t]{2}{*}{ Mean } & \multirow[t]{2}{*}{ Range } \\
\hline & & 2007 & 2008 & 2009 & 2010 & 2007 & 2008 & 2009 & 2010 & & \\
\hline P1 & Semi-permanent & 91 & 77 & 84 & 87 & Good & Good & Good & Good & 84.8 & 14 \\
\hline $\mathrm{P} 2 * * *$ & Semi-permanent & 51 & 48 & 57 & 80 & Fair & Fair & Fair & Good & 59.0 & 32 \\
\hline P3 & Semi-permanent & 66 & 66 & 55 & 66 & Good & Good & Fair & Good & 63.3 & 11 \\
\hline P4 & Semi-permanent & 45 & 65 & 65 & 72 & Fair & Fair & Fair & Good & 61.8 & 27 \\
\hline P6 & Semi-permanent & 61 & 65 & 71 & 87 & Fair & Fair & Good & Good & 71.0 & 26 \\
\hline $\mathrm{P} 7 * * *$ & Semi-permanent & 76 & 76 & 87 & 83 & Good & Good & Good & Good & 80.5 & 11 \\
\hline P8 & Semi-permanent & 95 & 91 & 81 & 91 & Good & Good & Good & Good & 89.5 & 14 \\
\hline $\mathrm{T} 2 *$ & Intermediate & 69 & 66 & 66 & 80 & Good & Good & Good & Good & 70.3 & 14 \\
\hline $\mathrm{T} 2 * *$ & Intermediate & 99 & 91 & 91 & 95 & V Good & V Good & V Good & V Good & 94.0 & 8 \\
\hline $\mathrm{T} 3$ & Seasonal & 91 & 87 & 79 & 91 & V Good & V Good & V Good & V Good & 87.0 & 8 \\
\hline $\mathrm{T} 4$ & Seasonal & 49 & 56 & 60 & 79 & Fair & Fair & Fair & Good & 61.0 & 30 \\
\hline $\mathrm{T} 5$ & Seasonal & 37 & 34 & 59 & 67 & Poor & Poor & Fair & Good & 49.3 & 33 \\
\hline T6 & Seasonal & 76 & 72 & 76 & 83 & Good & Good & Good & V Good & 76.8 & 11 \\
\hline $\mathrm{T} 7$ & Seasonal & 62 & 56 & 74 & 79 & Good & Fair & Good & V Good & 67.8 & 23 \\
\hline T8 & Seasonal & 56 & 55 & 69 & 73 & Fair & Fair & Good & Good & 63.3 & 18 \\
\hline $\mathrm{T} 9 * * *$ & Seasonal & 77 & 62 & 77 & 87 & Good & Good & Good & V Good & 75.8 & 25 \\
\hline $\mathrm{T} 10$ & Temporary & 48 & 49 & 52 & 61 & Fair & Fair & Fair & Fair & 52.5 & 13 \\
\hline
\end{tabular}

* scored using semi-permanent metric value ranges

** scored using seasonal metric value ranges

*** portion of wetland catchment located outside of study area and receives some anthropogenic disturbance 


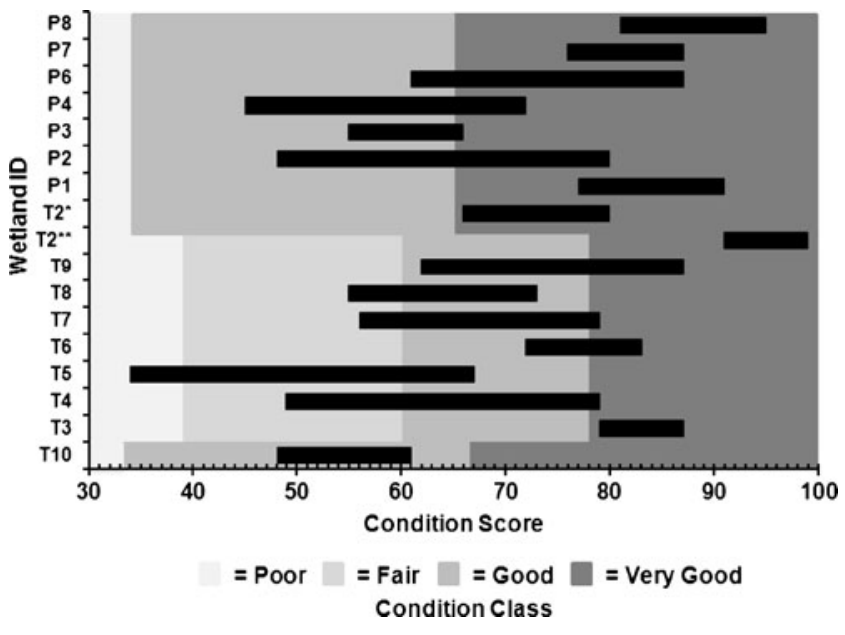

Fig. 2 Range (2007-2010) of Index of Plant Community Integrity (IPCI) condition scores (black horizontal bars) for 16 wetlands located in the Cottonwood Lake Study Area, Stutsman County, North Dakota. Note, condition class thresholds vary by wetland class (i.e., temporary, seasonal, semi-permanent) and large score ranges often cross condition thresholds. Wetland T2 was intermediate between a seasonal and semi-permanent classification and thus was rated twice, once using criteria for scoring seasonal wetlands (*) and again using criteria for semi-permanent wetlands $(* *)$

water-depth in seasonal wetlands was $0.24 \mathrm{~m}$ and $0.40 \mathrm{~m}$ in 2007 and 2009, respectively. Mean average-water-depth of semi-permanent wetlands varied from $1.45 \mathrm{~m}$ in 2008 to $1.96 \mathrm{~m}$ in 2010 . Mean average-water-depth in semipermanent wetlands was $1.74 \mathrm{~m}$ and $1.86 \mathrm{~m}$ in 2007 and 2009, respectively. While individual IPCI scores varied greatly over the 4 years of our study, the mean IPCI score of both seasonal and semipermenant wetlands displayed an increasing trend with increasing water levels (Fig. 3). The single temporary wetland sampled, wetland T10, did not have a staff gauge installed in it and thus water depth data are not available for this wetland. However, this wetland also displayed and increasing trend in IPCI scores over the course of our study (Table 2).

From Stewart and Kantrud's $(1971,1972)$ investigations, insights can be gained from the mean C-values calculated from their listing of dominant and secondary plant species for normal emergent, natural drawdown, and cropland drawdown phases. In all cases, plant species representative of normal emergent phases had substantially higher average $\mathrm{C}$-values than those of natural drawdown phases (Table 3), indicating that IPCI scores using metrics based on $\mathrm{C}$-values would also have lower rankings during the natural drawdown wetland phase. Also, we found that mean $\mathrm{C}$-values of the cropland phase were often greater than those of the natural drawdown phase (Table 3) thereby adding additional confusion to attempts to separate natural and anthropogenic disturbances during dry conditions.

\section{Discussion}

To be effective indicators of human impact on wetland ecosystems, IBIs should not vary in condition class over the range of conditions characteristic of natural ecosystem function. Despite this basic premise, IPCI scores for CLSA wetlands varied considerably among years, and the variation was sufficient in ten of our study wetlands $(62.5 \%)$ to result in changes in condition class even though anthropogenic disturbance remained constant. Our evaluation of IPCI scores for CLSA wetlands demonstrate that these scores are confounded by variation associated with natural wetland dynamics. This natural variation takes two interrelated forms: temporal variation as wetland hydrology and plant communities respond to natural climatic events and spatial variation among different wetland types along hydrogeochemical continua. Data provided here and in earlier studies (e.g., Harris and Marshall 1963; Weller and Spatcher 1965; van der Valk and Davis 1978; van der Valk 2005) demonstrate that prairie wetland biota are dynamic in their response to widely fluctuating climatic conditions. Wetland scientists have long recognized these dynamics
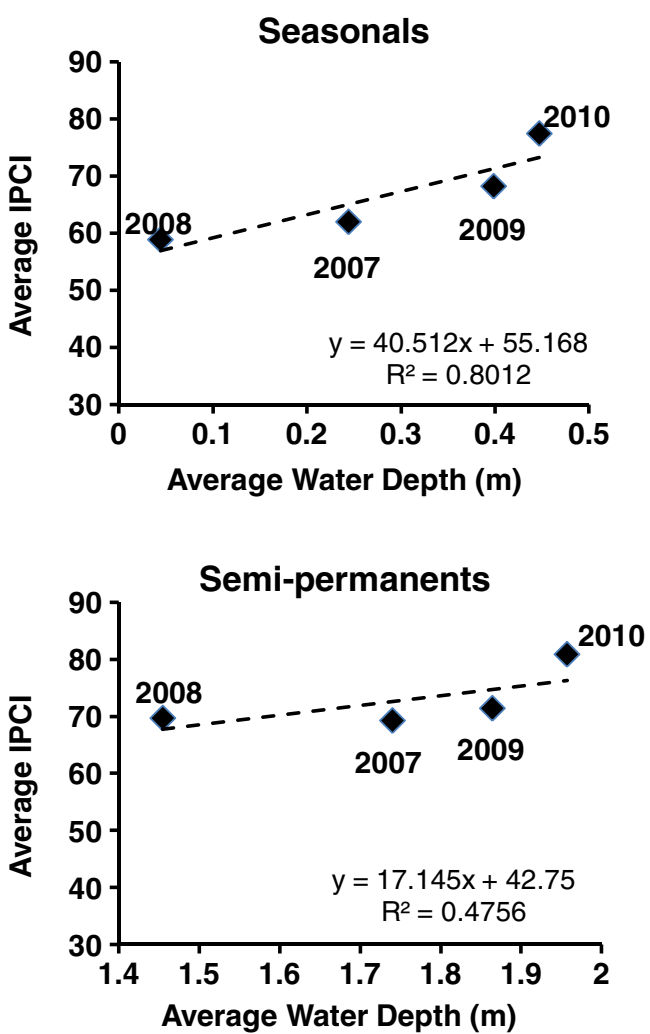

Fig. 3 Average Index of Plant Community Integrity (IPCI) scores plotted by average water depth for seven seasonal (T3, T4, T5, T6, T7, T8, T9) and seven semi-permanent (P1, P2, P3, P4, P6, P7, P8) wetlands at the Cottonwood Lake Study Area, Stutsman County, North Dakota, 2007 to 2010. Note increasing trend in IPCI scores (dashed lines) with increasing water depths 
Table 3 Mean coefficient of conservatism (C) values for the central zones of temporary (Class II), seasonal (Class III), and semipermanent (Class IV) wetlands under normal emergent, natural drawdown, and cropland drawdown phases. Mean C-values were derived from lists of dominant and secondary plant species defining each class, subclass, zone, and phase as provided in Stewart and Kantrud (1971)

\begin{tabular}{llllll}
\hline \multirow{2}{*}{ Class } & Subclass & Central zone & & Phase & \\
\cline { 5 - 6 } & & & Normal emergent & Natural drawdown & Cropland drawdown \\
\hline II (Temporary) & A-fresh & Wet-meadow & 3.90 & N/A & 0.33 \\
II (Temporary) & B-slightly brackish & Wet-meadow & 3.59 & N/A & 0.33 \\
III (Seasonal) & A-fresh & Shallow-marsh & 2.22 & 1.20 & 2.00 \\
III (Seasonal) & B-slightly brackish & Shallow-marsh & 3.15 & 1.14 & 2.00 \\
III (Seasonal) & C-moderately brackish & Shallow-marsh & 3.50 & 1.20 & 1.50 \\
IV (Semi-permanent) & A-fresh & Deep-marsh & 4.00 & 2.50 & N/A \\
IV (Semi-permanent) & B-slightly brackish & Deep-marsh & 2.40 & 1.33 & N/A \\
IV (Semi-permanent) & C-moderately brackish & Deep-marsh & 4.50 & 0.75 & N/A \\
IV (Semi-permanent) & D-brackish & Deep-marsh & 4.50 & 0.17 & N/A
\end{tabular}

and have purposefully drained and flooded wetlands to enhance waterfowl populations (Cook and Powers 1958; Kadlec and Smith 1992). Duplicating the sharp increase in wetland productivity (primarily seed production by annual plants) that occurs when wetlands dry and naturally reflood is a common goal of moist-soil management of wetlands to benefit wildlife (Fredrickson and Taylor 1982). Additionally, Niemuth et al. (2010) recently provided a summary detailing the great temporal and spatial variation of wetland hydrology in the PPR that currently confounds efforts to quantify or predict changes in wetland number, wet area, hydroperiod, and water levels resulting from climate change.

\section{Temporal Variation}

Shifts in plant community composition in prairie wetlands occur repeatedly over the natural hydrologic cycle as mudflat, emergent, submersed, and free-floating species appear and disappear from the visible wetland flora (van der Valk and Davis 1978). Welling et al. (1988) and van der Valk (2005) describe how annual species increase during drying events as mudflats become exposed and decrease when they are reflooded. These natural changes in annual species clearly influence IPCI metrics based on annual/perennial designations (four of the nine IPCI metrics). An additional four of the metrics used to calculate IPCI scores use Cvalues in their computation (i.e., number of species with a $\mathrm{C}$-value $\geq 5$, number of species in the wet meadow zone with a $\mathrm{C}$-value $\geq 4$, average $\mathrm{C}$-value, and floristic quality index). Since climate cycles result in temporal shifts between conservative emergent, submergent, and freefloating species to less conservative ephemeral species, many of which are annuals, IPCI scores and resulting condition ratings would logically shift in their response to natural cycles that periodically favor or disfavor species with differing $\mathrm{C}$-values (e.g., increases in higher $\mathrm{C}$-value conservative species during pluvial periods versus lower $\mathrm{C}$ value pioneering annuals during dry periods). Indeed, temporal variation in composition of prairie wetland plant communities has been recognized for a considerable time.

Fluctuations in climate conditions during the 4-year-period of our study were sufficient to result in $63 \%$ of the wetlands switching condition classes during this relatively short period. Three wetlands even switched wetland condition class more than once. The changes we observed occurred during a climate period when wetlands water levels generally increased from lowest levels in 2008 to highest levels in 2010 (Fig. 3). Winter and Rosenberry (1998) showed that the Palmer Drought Severity Index (PDSI; Palmer 1965) was strongly related to water levels of wetlands and concluded that the PDSI for Division 5 of North Dakota could be used to make inferences about past hydrologic functions of CLSA wetlands. The PDSI values for Division 5 (Fig. 4) reflect the increases we observed in water depths over the period of our study. However, Fig. 4 also reveals that the changes experienced during the 4-year-period of our study were relatively mild compared to potential water-level shifts between periods of drought and deluge that have occurred in the past (e.g., the early 1990s). During these earlier periods of more extreme climate change, it is likely that the plant community changes would also have been more extreme resulting in greater numbers and severities of shifts in IPCI ratings unrelated to changes in anthropogenic disturbance.

Our evaluation of data provided by Stewart and Kantrud (1971) provided additional evidence that variability in natural wetland cycles can be of sufficient magnitude to mask effects from anthropogenic disturbance (i.e., mean C- 


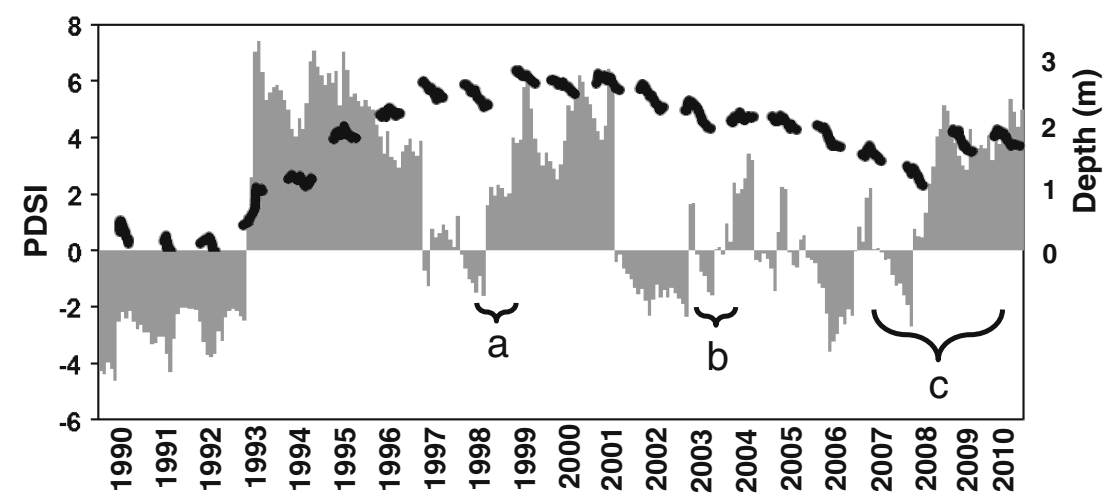

Fig. 4 The Palmer Drought Severity Index (PDSI) for Division 5 of North Dakota, 1990-2010 and water depth of wetland P1 (broken bolded lines) at the Cottonwood Lake Study Area, North Dakota. Negative PDSI values represent the presence and severity of drought events while positive values represent periods of abundant precipita-

values during natural drawdown phases are comparable to mean $\mathrm{C}$-values of the anthropogenically induced cropland drawdown phase). As an example, the mean $\mathrm{C}$-value of dominant and secondary plant species listed by Stewart and Kantrud (1971) for the central shallow-marsh zone of a slightly brackish seasonal (Class III) wetland was 3.15. This value drops to 1.14 during the natural drawdown phase which is below the mean C-value of 2.00 for the cropland drawdown phase. Thus, it is not surprising that IPCI metrics that utilize $\mathrm{C}$-values in their computation would be confounded by this overlap in mean $\mathrm{C}$-values between drawdown phases of natural wetlands and cropland phases of disturbed wetlands.

Hargiss et al. (2008) suggested that including information from upland communities in wetland plant community assessment methodologies can account for shifts of species between zones caused by hydrologic fluctuations and provide the ability to separate changes due to normal hydrologic change from changes due to human disturbance. However, studies have shown that significant changes in plant communities occur in wetlands as they cycle through hydrologic fluctuations that cannot be attributed to simple shifts in the spatial location of species into uplands or vice versa (e.g., Harris and Marshall 1963; van der Valk and Davis 1978; Welling et al. 1988; Euliss et al. 2004). For example, during dry periods, annual plants colonize exposed mudflats following germination from dormant seed banks in the wetland substrates and replace submersed and free-floating perennials in wetlands (van der Valk and Davis 1978; van der Valk 2005). This temporal pattern is a natural disturbance pattern in which annual plants that typically have low $\mathrm{C}$-values periodically replace perennial species that are generally more conservative and have correspondingly higher $\mathrm{C}$-values. Hence, natural climatic cycles would tend to increase IPCI scores during wet periods and lower them during natural drawdown cycles, tion. Also shown are the periods during which wetlands were sampled by a Dekeyser et al. (2003), b Hargiss et al. (2008), and c this study. Note, while Dekeyser et al. and Hargiss et al. each sampled over a 2-year-period, each wetland was only sampled in a single year

even in the absence of anthropogenic disturbance. Indeed, this is the trend we observed over the 4 years of our study (Fig. 3). Further, IPCIs are based on one-time visits (DeKeyser et al. 2003; Hargiss et al. 2008) so locations of wetland zones are defined by locations of plant species at the time of the survey. Hence, surveyors have no prior knowledge of previous zone locations and therefore sample plant communities in the locations where they currently exist (i.e., if wet-meadow species have moved uphill in response to rising water levels, the plants would be sampled at this new higher elevation and still be included in any comprehensive species listing even if the low prairie zone was not sampled). In our long-term study at CLSA even with our prior knowledge of the location of individual zones, we still must delineate wetland zones annually to account for temporal shifts in zone locations as wetland pools naturally rise and fall in response to climate cycles.

Although they interpreted their findings differently, our conclusions that IPCI metric and condition scores are confounded by climate variation are consistent with the findings of Hargiss et al. (2008). Hargiss et al. (2008) sampled in areas that received normal to above normal precipitation and also in an area experiencing drought (i.e., south central North Dakota). In the region experiencing drought, only a single wetland in high-quality native prairie ranked in the good condition class across all temporary, seasonal, and semi-permanent wetlands they sampled. Hargiss et al. (2008) hypothesized that the poor quality ratings of these wetlands may have been due to greater habitat fragmentation in this region versus the other regions they sampled. However, a more parsimonious explanation of the low IPCI scores they report is that IPCI condition scores decreased in response to drought conditions resulting in reduced quality ratings in the region experiencing drought. Likewise, higher condition scores and condition ratings were found in the regions experiencing more pluvial conditions. 
Spatial Variation

Consideration of the continuous nature of prairie wetlands along hydrologic gradients further illustrates why development of IBI's for prairie pothole wetlands have been problematic. Wetlands, due to the continuous nature of their characteristics and dynamics, do not fit into neat catagories (Meybloom 1963; Lissey 1971; Stewart and Kantrud 1971; Cowardin et al. 1979; Euliss et al. 2004). The IPCI described by DeKeyser et al. (2003) and Hargiss et al. (2008) relies on placing wetlands into one of only three discrete wetland classes (temporary, seasonal, or semi-permanent) and does not consider the continuous nature of wetlands along hydrologic gradients or the hydrogeochemical processes driving their ecology (Euliss et al. 2004). Stewart and Kantrud (1972) provided several examples of wetlands that fall at intermediate locations between the wetland classes they describe in their classic treatment of prairie wetlands. However, the metric value ranges of Hargiss et al. (2008) do not account for wetlands that occupy intermediate positions between classes. As an example, using the methodology of Hargiss et al. (2008), a seasonal wetland must contain at least 42 native perennial plant species to obtain the highest score of 11 . However, for a semi-permanent wetland, 72 native perennial species must be present to receive the same score. A wetland falling between the hydrologic regime of a seasonal and semi-permanent wetland would be scored too high if it is forced into the seasonal classification or too low if it is forced into the semi-permanent classification for ranking. CLSA wetland T2 is an example of an intermediate wetland that does not fit neatly into either the seasonal or semi-permanent classification. Using the IPCI methodology, this wetland was classified into different condition classes based on whether a seasonal or semi-permanent scoring range was used (Table 2). Also, wetlands that do fit neatly into a single classification can have very different chemical properties and resultant plant communities due to differing relationships to groundwater (Euliss et al. 2004). Stewart and Kantrud (1971) accounted for these differences by adding subclasses (i.e., fresh, slightly brackish, moderately brackish, brackish, subsaline, and saline) to their wetland classification system. As wetlands become saltier than a species can tolerate due to their position on hydrogeochemical and climate continua, that species is eliminated from the standing plant community. Plants tolerant of moderately brackish or brackish semi-permanent wetland subclasses typically have high average $\mathrm{C}$-values (mean $=4.50$; Table 3 ). During natural drawdowns, these species are replaced by species that have significantly lower $\mathrm{C}$-values (mean $=0.75$ for moderately brackish and 0.17 for brackish; Table 3). Thus, processes within naturally functioning wetlands also contribute to temporal variation in IPCI scores independent of human disturbance.
Herricks and Schaeffer (1985) identified six criteria necessary for biomonitoring programs.

1) The measure must be biological.

2) The measure must be interpretable at several trophic levels or provide a connection to other organisms not directly monitored.

3) The measure must be sensitive to the environmental conditions being monitored.

4) The response range of the measure must be suitable for the intended application.

5) The measure must be reproducible and precise within defined and acceptable limits for data collection over space and time.

6) The variability of the measure must be low.

The two criteria that are the most troublesome for prairie wetland IBI development are the same two criteria that were not satisfied in the Wilcox et al. (2002) evaluation of Great Lakes wetlands IBIs: "The measure must be reproducible and precise within defined and acceptable limits for data collection over space and time" and "The variability of the measure must be low." Given the high natural variability of prairie wetlands in space and time, we do not believe it likely that IBI metrics can be identified that are useful and cost effective to implement in highly dynamic wetland systems such as prairie pothole wetlands.

\section{Conclusions}

Our study is the first to evaluate IPCI scores for wetlands over a temporal period spanning more than a single year. Our evaluation demonstrates significant change in IPCI condition scores for the wetlands we studied over a 4-year period that did not correspond to changes in anthropogenic disturbance. These findings corroborate the findings of Wilcox et al. (2002), who concluded that hydrologic variability would often render IBIs for plants, fish, and invertebrates invalid; they specifically suggested that the PPR would be especially problematic. Our conclusions also are consistent with Tangen et al. (2003) who were unable to develop IBIs for prairie wetlands using aquatic invertebrates. Our evaluation demonstrated that IPCI metric scores, condition scores, and overall condition ratings varied in naturally functioning prairie pothole wetlands and highlights the problem of identifying metrics that can separate natural and anthropogenic influences in variable ecosystems. Further, IBI metrics should be able to pass the screening process outlined by Whittier et al. (2007) to effectively separate natural from anthropogenic disturbance. They utilized a signal to noise ratio test to measure the repeatability or precision of various metrics. The high level of noise in IPCI scores we observed demonstrates how 
natural climate variability could mask an anthropogenic disturbance signal. Additionally, Whittier et al. (2007) recommended rejecting metrics that were correlated with natural gradients. However, the naturally steep hydrologic gradients of prairie wetlands from groundwater recharge to groundwater discharge that can naturally change the composition of the entire biological community of prairie wetlands (Euliss et al. 1999, 2004) were not considered in the selection of IPCI metrics. Finally, the metrics used by DeKeyser et al. (2003) and Hargiss et al. (2008) were of two basic types with one including richness and the other using C-values; hence, most of the individual metrics they used were correlated (e.g., species richness of native perennials versus number of genera of native perennials, and number of species with a $\mathrm{C}$-value $\geq 5$ versus average $\mathrm{C}$-value). Thus, the redundancy test outlined by Whittier et al. (2007) (i.e. elimination of metrics that explain much of the same variation in biotic integrity) would exclude most IPCI metrics.

We conclude that development of IBIs for prairie pothole wetlands still have major logistic challenges to overcome. As noted by Wilcox et al. (2002), IBIs for Great Lakes wetlands would require as many as 30 sets of scoring criteria to define all possible permutations of expression of the biotic community in the naturally functioning biological community, given the quasi-periodic hydrologic behavior of the lakes (Baedke and Thompon 2000). For prairie pothole wetlands, it is even more complex because enumerable separate scoring criteria would be required to reflect the continuous gradients in geochemistry and hydrologic function of prairie pothole wetlands. At a minimum, separate scoring criteria would be required for each wetland class, salinity subclasses within each wetland class, and hydrologic phases within each subclass as identified by Stewart and Kantrud (1971). Additional categories accounting for natural overland outlets and connectivity among adjacent wetlands would also need to be included. Integrated within this classification would need to be methodology to account for natural, inter-annual, climate-driven fluctuations within each class, subclass, and hydrologic phase.

Given the dynamic climate and hydrologic conditions of the region, and the corresponding variation in biotic communities both among years and among wetlands within years, we conclude that development of IBIs that account for and partition natural variations in prairie pothole wetlands from variation attributable to human disturbance remains an elusive goal. We concur with Wilcox et al. (2002) that development of IBIs will face similar challenges in other ecosystems where naturally dynamic climate conditions markedly influence the composition of biotic communities. We also suggest that use of IBIs that do not adequately separate variation in natural noise from the variation due to anthropogenic disturbance could result in serious conservation mishaps. Indeed, a normally functioning wetland could inappropriately receive a poor condition score and lead to the initiation of an unnecessary conservation or regulatory action that may negatively impact wetland function and potentially erode public confidence in the wetland sciences.

Acknowledgments We thank Stephen P. Lane for conducting comprehensive plant surveys of wetlands at the Cottonwood lake Study Area over a 13-year-period, and Loren Smith, Douglas Wilcox, and Edward DeKeyser for providing helpful reviews of earlier versions of this manuscript. We also thank Walter Duffy, Nels Troelstrup, and two anonymous reviewers for their comments on our paper.

\section{References}

Baedke SJ, Thompon TA (2000) A 4,700-year record of lake level and isostasy for Lake Michigan. Journal of Great Lakes Research 26:416-426

Cook HH, Powers CF (1958) Early biochemical changes in the soils and waters of artificially created marshes in New York. New York Fish and Game Journal 5:9-65

Cowardin LM, Carter V, Golet FC, LaRoe ET (1979) Classification of wetlands and deepwater habitats of the United States. U.S. Fish and Wildlife Service FWS/OBS/-79/31, Washington DC

DeKeyser ES (2000) A vegetative classification of seasonal and temporary wetlands across a disturbance gradient using a multimetric approach. $\mathrm{Ph}$.D. Dissertation. North Dakota State University, Fargo

DeKeyser ES, Kirby DR, Ell MJ (2003) An index of plant community integrity: development of the methodology for assessing prairie wetland plant communities. Ecological Indicators 3:119-133

DeKeyser ES, Biondini M, Kirby D, Hargiss C (2009) Low prairie plant communities of wetlands as a function of disturbance: physical parameters. Ecological Indicators 9:296-306

Euliss NH Jr, LaBaugh JW, Fredrickson LH, Mushet DM, Laubhan MK, Swanson GA, Winter TC, Rosenberry DO, Nelson RD (2004) The wetland continuum: a conceptual framework for interpreting biological studies. Wetlands 24:448-458

Fredrickson LH, Taylor TS (1982) Management of seasonally flooded impoundments for wildlife. U.S. Fish and Wildlife Service, Resource Publication 148, Washington DC

Hanson JD, Castelle AJ (2001) Using terrestrial insects for ecological assessments of wetlands. Wetland Journal 13:24-28

Hargiss CLM, DeKeyser ES, Kirby DR, Ell MJ (2008) Regional assessment of wetland plant communities using the index of plant community integrity. Ecological Indicators 8:303-307

Harris SW, Marshall WH (1963) Ecology of water-level manipulations on a northern marsh. Ecology 44:331-343

Herricks EE, Schaeffer DJ (1985) Can we optimize biomonitoring? Environmental Management 9:487-492

Higgens KF (1984) Lightning fires in North Dakota grasslands and in pine-savanna lands of South Dakota and Montana. Journal of Range Management 37:100-103

Kadlec JA, Smith LM (1992) Habitat management for breeding areas. In: Batt BDJ, Afton AD, Anderson MG, Ankney CD, Johnson DH, Kadlec JA, Krapu GL (eds) Ecology and management of breeding waterfowl. University of Minnesota Press, Minneapolis, pp 590-610

Kantrud HA, Newton WE (1996) A test of vegetation-related indicators of wetland quality in the prairie pothole region. Journal of Aquatic Ecosystem Health 5:177-191 
Karr JR (1981) Assessment of biotic integrity using fish communities. Fisheries 6:21-27

Karr JR (1991) Biological integrity: a long-neglected aspect of water resource management. Ecological Applications 1:66-84

Karr JR, Chu EW (1997) Biological monitoring: essential foundation for ecological risk assessment. Human and Ecological Risk Assessment 3:993-1004

Karr JR, Fausch KD, Angermeier PL, Yant PR, Schlosser IJ (1986) Assessing biological integrity in running waters: a method and its rationale. Illinois Natural History Survey Special Publication 5

Kirby DR, DeKeyser ES (2003) Index of wetland biological integrity development and assessment of semi-permanent wetlands in the Missouri Coteau Region of North Dakota. Final Report for North Dakota Department of Health. Section 104[b] (3) Wetland Grant Funds

Labaugh JW (2003) Spatial and temporal variability in specific conductance and chemical characteristics of wetland water and in water column biota in the wetlands in the Cottonwood Lake area. In: Winter TC (ed) Hydrological, chemical, and biological characteristics of a prairie pothole wetland complex under highly variable climate conditions - the Cottonwood Lake area, east-central North Dakota. U.S. Geological Survey Professional Paper 1675, pp 35-53

Lissey A (1971) Depression-focused transient groundwater flow patterns in Manitoba. Geological Association of Canada Special Paper 9:333-341

Mack JJ (2007) Developing a wetland IBI with statewide application after multiple testing iterations. Ecological Indicators 7:864-881

McNaughton SJ (1979) Grazing as an optimization process: grassungulate relationships in the Serengeti. American Midland Naturalist 113:691-703

McNaughton SJ (1986) On plants and herbivores. American Midland Naturalist 128:765-770

Meybloom P (1963) Patterns of ground-water flow in the prairie profile. Proceedings of Hydrology Symposium Number 3, Groundwater. Queen's Printer, Ottawa, Canada

Miller SJ, Wardrop DH, Mahaney WM, Brooks RP (2006) A plant based index of biological integrity (IBI) for headwater wetlands in central Pennsylvania. Ecological Indicators 6:290-312

Mushet DM, Euliss NH Jr, Shaffer TL (2002) Floristic quality assessment of one natural and three restored wetland complexes in North Dakota, USA. Wetlands 22:126-138

Mushet DM, Euliss NH Jr, Lane SP, Goldade CM (2004) The flora of the Cottonwood Lake Study Area, Stutsman County, North Dakota. Prairie Naturalist 36:43-62

Nelson JG, England RE (1971) Some comments on the cause and effects of fire in the northern grassland areas of Canada and the nearby United States, ca 1750-1900. Canadian Geographer 15:295-306

Niemuth ND, Wangler B, Reynolds RE (2010) Spatial and temporal variation in wet area of wetlands in the prairie pothole region of North Dakota and South Dakota. Wetlands 30:1053-1064

Northern Great Plains Floristic Quality Assessment Panel (2001) Coefficients of conservatism for the vascular flora of the Dakotas and adjacent grasslands. U.S. Geological Survey, Biological Resources Division, Information and Technology Report USGS/ BRD/ITR-2001-0001

Palmer WC (1965) Meteorologic drought. U.S. Weather Bureau, Research Paper No 45

Raby S (1966) Prairie fires in the Northwest. Saskatchewan History 19:81-99

Rosenberry DO (2003) Climate of the Cottonwood Lake area. In: Winter TC (ed) Hydrological, chemical, and biological characteristics of a prairie pothole wetland complex under highly variable climate conditions - the Cottonwood Lake area, east-central North Dakota. U.S. Geological Survey Professional Paper 1675, pp 25-34

Simon TP, Stewart PM, Rothrock PE (2001) Development of multimetric indices of biotic integrity for riverine and palustrine wetland plant communities along Southern Lake Michigan. Aquatic Ecosystem Health and Management 4:293-309

Stewart RE, Kantrud HA (1971) Classification of natural ponds and lakes in the glaciated prairie region. U.S. Fish and Wildlife Service Professional Paper 585-D

Stewart RE, Kantrud HA (1972) Vegetation of prairie potholes, North Dakota, in relation to quality of water and other environmental factors. U.S. Geological Survey Professional Paper 585-D

Swink FA, Wilhelm GS (1994) Plants of the Chicago Region, 4th edn. Indiana Academy of Science, Indianapolis

Taft JB, Wilhelm GS, Ladd DM, Masters LA (1997) Floristic quality assessment for vegetation in Illinois, a method for assessing vegetation integrity. Erigenia 15:3-95

Tangen BA, Butler MG, Ell MJ (2003) Weak correspondence between macroinvertebrate assemblages and land use in prairie pothole region wetlands, USA. Wetlands 23:104-115

van der Valk AG (2005) Water-level fluctuations in North American prairie wetlands. Hydrobiologia 539:171-188

van der Valk AG, Davis CB (1978) The role of seed banks in the vegetation dynamics of prairie glacial marshes. Ecology 59:322-335

Weller MW, Spatcher CS (1965) Role of habitat in the distribution and abundance of marsh birds. Iowa Agriculture and Home Economics Experimental Station, Ames, Special Report 43

Welling CH, Pederson RL, van der Valk AG (1988) Recruitment from the seed bank and the development of zonation of emergent vegetation during a drawdown in a prairie wetland. Journal of Ecology 76:483-496

Wilcox DA, Meeker JE, Hudson PL, Armitage BJ, Black MG, Uzarski DG (2002) Hydrologic variability and the application of index of biotic integrity metrics to wetlands: a Great Lakes evaluation. Wetlands 22:588-615

Wilhelm GS, Ladd D (1988) Natural area assessment in the Chicago region. Transactions of the North American Wildlife and Natural Resources Conference 53:361-375

Winter TC (1987) Hydrology of the Cottonwood Lake area Stutsman County, North Dakota. Proceedings of the North Dakota Academy of Sciences 41:27

Winter TC (1989) Hydrologic studies of wetlands in the Northern Prairie. In: van der Valk AG (ed) Northern prairie wetlands. Iowa State University Press, Ames, pp 16-54

Winter TC (2003a) Geohydrologic setting of the Cottonwood Lake area. In: Winter TC (ed) Hydrological, chemical, and biological characteristics of a prairie pothole wetland complex under highly variable climate conditions - the Cottonwood Lake area, east-central North Dakota. U.S. Geological Survey Professional Paper 1675, pp 1-24

Winter TC (2003b) Foreword. In: Winter TC (ed) Hydrological, chemical, and biological characteristics of a prairie pothole wetland complex under highly variable climate conditionsthe Cottonwood Lake area, east-central North Dakota. U.S. Geological Survey Professional Paper 1675, p III

Winter TC, Rosenberry DO (1995) The interaction of groundwater with prairie wetlands in the Cottonwood Lake area, east-central North Dakota, 1979-1999. Wetlands 15:193-211

Winter TC, Rosenberry DO (1998) Hydrology of prairie pothole wetlands during drought and deluge: a 17-year study of the Cottonwood Lake wetland complex in North Dakota in the perspective of longer term measured and proxy hydrological records. Climatic Change 40:189-209

Whittier TR, Hughes RM, Stoddard JL, Lomnicky GA, Peck DV, Herlihy AT (2007) A structured approach for developing indices of biotic integrity: three examples from streams and rivers in the Western USA. Transactions of the American Fisheries Society 136:718-735

Woodhouse CA, Overpeck JT (1998) 2000 years of drought variability in the central United States. Bulletin of the American Meteorological Society 79:2693-2714 